\title{
Removal of Public Officers from Office: Law and Justice in a Flux
}

\author{
Kayode O. Fayokun ${ }^{1}$
}

\section{(C) Uganda Martyrs University}

\begin{abstract}
This paper examined the state of the law on removal of public officers from office. It observed that there are competing interests of labour and industry to be served by the rules on disengagement from public office. Workers need security of employment while industries need discipline and efficiency to survive. The courts have striven with changing trends in ensuring balance and justice for both the workers and the industries. The author's appraisal of case law puts in view the state of both substantive and procedural law on the discipline of public officers as expounded by judges in the exercise of their power of judicial review. On the one hand is the attempt to maintain freedom of contract, which assumes the equal bargaining power of the parties. On the other hand is the need to give effect to statutory provisions which secure the tenure of public officers above that of the ordinary employee through legislation. The paper concluded that the divergent interests are not necessarily in conflict; they can be reconciled and adjusted to be mutually complementary.
\end{abstract}

Keywords $\cdot$ Public officers $\cdot$ Discipline $\cdot$ Public management

\section{Introduction}

Good discipline enhances efficiency in any organisation both in the public and private sector. Kothari, Kothari and Saran (2008) defines good discipline as orderly conduct of affairs by the members of an organisation who adhere to its necessary regulations because they desire to co-operate harmoniously in forwarding the ends which the group has in view and willingly recognize that to do this their own wishes must be brought into reasonable unison with the requirements of the group in action. They opined that the establishment of good discipline is a joint responsibility of both employers and the employees.

Good discipline requires the input of both management and their employees. Good discipline breeds better performance. It is for this reason that the employer and employee enter into agreement on the rules and regulations governing their conditions of service. The foremost thing is to see that every member of the organisation knows what is expected of him and to have the members of the group seeing that what is to be done is done. The

\footnotetext{
${ }^{1}$ Faculty of Law, Obafemi Awolowo University, Ile-Ife. E-mail: kfayokun@yahoo.com
} 
breach of the rules should be least expected but envisaged by designing a disciplinary plan. The disciplinary plan should be proactive, inclusive of statement of the rules, imposition of penalties and the sharing of responsibilities in an organised way.

\section{Statement of the Problem}

There are seemingly conflicting claims involved in the tenure of public officers. The public service is in need of discipline and efficiency to survive and prosper. Thus, the employer seeks to purge the system of clogs in the wheel of progress and maintain standards. However, public servants must be protected from tyrants who subvert the machinery of state for private pursuits. Modern industrial jurisprudence must evolve principles to reconcile the interests of both employer and employee in the public sector. Are the respective interests of management and their workmen in conflict? Are these conflicting interests irreconcilable? Are they merely superficial and mutually complementary? Where both labour and industry lay claims to legal protection in their conditions of service, how are these claims to be best protected when there is overbearing influence of one party to the contract of service? How have the courts (in the course of judicial review), tried to maintain the balance between the interests the employer by upholding discipline in an organisation while at the same time securing the security of job of the employee? There is the need to closely examine the state of the law in the search for justice for both management and labour.

\section{Public Service Dichotomy}

Public service in Nigeria encompasses service in government departments, agencies ${ }^{\mathrm{a}}$ as well as statutory or public corporations. Sometimes employees of limited liability companies where government has controlling shares are referred to as public servants. Generally, public servants have their services governed by the Public Service Rules. However, their conditions of service may be found in several other documents including their letters of appointment. For those working directly in government departments (called civil servants), there is a uniform Civil Service Rules governing their tenure of service. For the purpose of security of tenure, Nigeria judges draw a distinction between employees in the private and public sector on the one hand, and in the public service, between civil servants and other public servants on the other hand. With regard to the procedure for their removal from office, civil servants rely on the Civil Service Rules for their conditions of service. The Rules contain elaborate provisions on appointment, tenure and removal procedures. Other public servants depend on their appointment contracts and sometimes statutory instruments specifying their conditions of service.

In Sule v. Nigeria Cotton Board ${ }^{\mathrm{b}}$, the plaintiff was employed in the Department of Agriculture in 1944. The Nigerian Cotton Board was set up under the Commodity Board Act, 1977. On the creation of the Nigerian Cotton Board, the plaintiff transferred his services to the defendant company and his appointment was deemed to take effect with the defendant company from $1^{\text {st }}$ April 1977. The plaintiff was transferred from Lagos to Funtua by the defendant and he was required to vacate his quarters at No 13A Dakar Road, Apapa, Lagos, for Alhaji Jimeta who was simultaneously transferred from Funtua to Lagos. The plaintiff reported for duty at Funtua but he refused to vacate the quarters at No. 13A Dakar Road, Apapa, Lagos, on the ground that there was no place for him to put 
members of his family. On the $11^{\text {th }}$ of April, 1979, the defendant wrote a letter to the plaintiff retiring him with full benefits from defendant's service and requesting him to vacate the quarters after a period of one month's grace. The plaintiff contended that he was a civil servant and under the Civil Service Rules, his employment was secured until the retiring age of 60 years. That as such, only the Minister of Pensions, not the Board, could retire him from service. It was held that the plaintiff was a staff of the defendant and that it was never intended that a staff of the defendant company be governed by the Civil Service Rules.

In Daniel v. Adaji ${ }^{\mathrm{c}}$ it was held, that the Court of Appeal, that the National Electric Power Authority (NEPA) formed part of the public service of the Federation. In Okomu Oil Palm Co. Ltd. V. Iserhienrhien ${ }^{\mathrm{d}}$, the appellant was an incorporated company in which the Federal government held majority shares. It employed the respondent whose appointment was later terminated. The respondent sought a declaration to invalidate the termination. He argued that since the company was government-funded, he was a civil servant and as such the appellant should have complied with the Civil Service Rules before his termination. It was held by the Supreme Court that before the respondent can take benefit of the Civil Service Rules, he must prove that he was employed by the Civil Service Commission. In Nigeria Airways Ltd. v. Okutubo ${ }^{\mathrm{e}}$ the respondent contended that his appointment was governed by the Federal Civil Service rules. It was held by the Court of appeal that since the Appellant is not a ministry or an extension of office of the President etc. the Civil Service Rules cannot apply.

The dichotomy between civil service and public service is enshrined in the 1999 Constitution. Section 318 of the constitution defines the "Civil Service" as "service in a civil capacity as staff of the office" of the President, the Vice-President, Governor, Deputy Governor or a ministry or department of the government. Public service on the other hand means "the service of the federation (or state) in any capacity in respect of the government" and it includes service as clerk of the National Assembly (or House of Assembly), Judiciary staff, member or staff of commission or authority established by law, staff of area or local government council, staff of statutory corporation, staff or educational institution established or financed by government or its agency holds controlling shares or interest and members or officers of the armed forces, police or other government security agencies established by law.

Herein lies the distinction between a civil servant and a public servant. As the Court of Appeal observed in Nigeria Airways Ltd. v. Okutubo ${ }^{f}$, where the respondent contended that his appointment was governed the Federal Civil Service Rules. It was held that the rules cannot apply since the appellant was not a ministry or extension of the office of the President etc.

\section{Status of Public Servants}

The idea that public servants hold their appointments at the pleasure of the state which can dismiss them at will has no place in Nigerian law. The Supreme Court in Shitta-Bey v. Federal Public Service Commission ${ }^{\mathrm{g}}$ has put an end to the right of the state to dismiss its servants at will hitherto considered as part of the Crown's progressive rights applicable in Nigeria both before and after independence. It was held that "the Civil Service Rule invests in these public servants a legal status; they can be properly or legally removed only as provided by the said rules". Accordingly, the principle of law which precludes 
mandamus from issuing against the Crown has historical justification in English legal history and there is no basis for its application in Nigeria (a Republic), there being no provision for it in any enactment in pour statute books.

It is now settled law that there are roughly three categories of contracts of employment in Nigeria ${ }^{\mathrm{h}}$, viz:

a) the purely master and servant contract of employment

b) the regulated contract of employment having statutory flavour

c) the hybrid form of the above two categories

In a contract of employment classified as purely master and servant relationship the parties are bound solely by the terms of contract between them. Where in such a contract provisions for the termination of the contract have been reduced into writing and the provisions are followed or complied with a servant whose appointment was terminated by his employer cannot complain of breach of contract ${ }^{\mathrm{i}}$.

In the ordinary case of master and servant the employment is personal and confidential. The master can terminate the contract with his employee or servant at any time for good or for bad reasons or for none. Motive which impelled am employer to terminate such contract of employment has never been relevant to validity of the exercise of the employer's right to dispense with the services of his employee ${ }^{\mathrm{j}}$.

Where an employee is guilty of gross misconduct, he could be discharged from the employment without notice and without wages ${ }^{\mathrm{k}}$. There is no fixed rule of law defining the degree of misconduct which would justify a dismissal. It is enough that the conduct of the servant is of a grave and weighty character as to undermine the confidence which should exist between him and the master ${ }^{12}$ In the law of master and servant, a misconduct is what the employer considers to be a misconduct. Working against the deep interests of the employer clearly amount to gross misconduct entailing the employer to peremptorily dismiss the employer irrespective of the condition of service. 13

Under the common law, since an ordinary master and servant relationship is personal and confidential, the court will hardly order a reinstatement or specific performance of contract for wrongful dismissal. No court will ordinarily compel an unwilling employer to continue keeping an employee just as an employee cannot be prevented from resigning his employment to seek greener pastures.

\section{Employment with Statutory Flavour}

The position of the law is completely different where employment is clothed with statutory flavour. In Olaniyan v. University of Lagos 14, it was held that, where a contract of service or the relationship of master and servant is predicated upon statute, then the employment is regulated and binding as a statutory provision. The Supreme Court categorically stated that in Nigeria, public servants in the established and pensionable cadre of the Federal Government Service do not hold their offices at the pleasure of the federal Government or anybody at all. Rather, their appointments are based upon rules, regulations or statutory instruments. The Rules confer on the public servant a status which makes his relations with his employer go beyond that of the ordinary or mere master and servant.

On the meaning of "employment with statutory flavour, it was held in CBN v. Igwillo" 15 that an employment is with statutory flavour when the appointment is protected by statue or laid down regulations (deriving from statue) made to govern the procedure for 
employment and discipline of an employee. Any other employment outside that category is governed by the terms under which the parties agreed to be master and servant 16 .

What is the legal position of an employment with statutory flavour? The status of a public servant, whose employment enjoys statutory flavour, is different from that of the ordinary servant. The court, in a long list of decisions, 17 have held that public servants whose employment are with statutory flavour enjoy security of tenure. They are not to be removed from office except in strict compliance with their conditions of service. Expounding on the position of the law, Emeka Chianu (2004) reiterated as follows:

"when a statutory body employs persons two legal rules come into conflict: administrative law because the employer is a statutory body, and the law of contract because the employer/employee relationship is contractual". 18

Thus, the public servant acquires a status which elevates him Above the ordinary servant. He cannot be removed from office without compliance with administrative rules and the rules governing his employment.

"A civil servant or a public servant for that matter is not in the same position as a servant in a simple case of master and servant. Therefore, if these are incidents of an employment that had been laid down by statute, or the employment was derived for statute, the Courts have always come in aid of the employee to enquire whether the procedural requirements laid down by statute had been complied with and also whether the dismissal or disciplinary action taken against the employee violates the rules of natural justice"19.

Where a public servant complains of being unjustly removed from service by a statutory body, the court have always maintained that the rules must be complied with. Noncompliance invalidates the act of removal at all times.

"To remove a public servant in flagrant contravention of the Rules governing him, whether under contract or under provisions of a Statute or Regulations made there under, is to act capriciously and to destabilize the security of tenure of the public servant, frustrate his hopes and aspirations, and thereby act in a manner inimical to order, good government and the well-being of society" 20.

Thus, it is settled law that public employees may only be removed from office after procedural requirements have been followed, otherwise the removal would be declared void. 21

In other words, non-compliance having not effected any change of position, the act being invalid at all times, there is no removal at all and the employee is returned to his position.

Of first importance in disciplinary process is that administrative bodies are bound to observe the rules of natural justice. 22 The twin pillar of the principles of natural justice are expressed in two maxims a) nemo judex in causa sua (no man shall be a judge in his own cause) and (b) audi alterem partem - (The two sides of a dispute must be heard).

Under the second maxim, i.e. the right to be heard, each party must be given an opportunity of stating his case and answering, is he can, any arguments put forward against it 23. Thus, a person liable to be directly affected by proposed administrative acts, decisions or proceedings or against whom disciplinary actions is proposed must be clearly informed of the allegations against him and be given opportunity to answer those 
allegations or charges before action is taken against him.24 Moreover, fair hearing being a Constitutional and fundamental requirement under law, an employer, before dismissing his employee must satisfy the constitutional requirement of fair hearing. The employer must ensure that from all the circumstances of the case, the allegations against such employee are sufficiently brought to his notice and adequate time is given to such employee to reply to those allegations. 25

Of equal important is the fact that administrative action is subject to judicial review. Thus, the removal of public officers from office is to be viewed from administrative law perspective rather than in contract law. The Supreme Court however, reiterated in Imoloeme v. West African Examination Council 26 that the mere fact the employer is a statutory body does not necessarily take the employment out of the ordinary master and servant relationship.

"It is not correct to argue that because (conditions service were) made pursuant to section 4(3) of (WAEC) Act 1973, the tenure of all appointments which enjoy the conditions of service are protected by statute".

In Fakuade v. OAUTHC 27, the Supreme Court further concretised this position by stating that:

"The fact that respondent is the creation of a statute does not elevate all its employees to the status or that the status of master and servant is no longer existent or that their employment or determination of their appointment must necessarily have a statutory flavour".28

On the relevant documents which the court will consider in determining a valid determination of master - servant relationship, it was held the court must confine itself, to the plain words and meaning which can be derived from the terms of the contract of service which are contained in the employee's letter of appointment and the Staff Regulations and Conditions of Service that must be construed and nothing else.

"The fact that the respondent employer is a statutory body does not mean that the conditions of service of its employees must be of a special character thereby ruling out the relationship of mere master and servant".

Looking closely at the trend of judicial pronouncements (in the above cases) in relation to the removal of public officers, are these decisions not contradictory?

In Aiyetan v Nigerian Institute for oil Palm Research 29 the appellant who was Assistant Executive Officer at NIFOR was suddenly retired from office with no charge against him and no hearing afforded him. The Respondent was a creation which stipulated that rules and regulating the employment of its staff may be made by the research institute, but none had been made at the relevant time. It was held by the Supreme Court that in the absence of statutory provisions, the Respondent being a public body is bound by the principles of natural justice as laid down in section 33 of the 1979 constitution. The appellant was therefore entitled to be reinstated to his office. In Inoloame v WAEC 30 the appellant was an Assistant Registrar and Branch Controller who challenged his removal from office by WAEC without due process. The respondent was a statutory body set up under the WAEC Act 1973. Section 4(3) of that Act enjoins the respondent to make regulations determining the conditions of service of its employee. One was made and the appellant relied on it. It was held by the Supreme Court that because conditions of service 
were made pursuant to section 4(3) of the WAEC Act 1973 does not make the tenure of all appointments which enjoy these conditions of service to be protected by statute.

In WAEC v. Akinkunmi 31 the Court of Appeal relied on the same WAEC Act and held that since WAEC was an administrative body established by statute its actions and decisions are subject to judicial review. Similarly, in Adeyemi v. WAEC 32 it was held that an administrative body such as WAEC is bound by the rules of natural justice.

In Fakuade 33 the appellant was a nursing officer in the OAUTHC, the respondent's hospital. The respondent, a statutory body was set up by the University Teaching Hospitals (Reconstitution of Boards, etc.) Act 1985. Section 9 of the respondent's statute has provision for the removal of "any person employed as a member of the clinical, administrative or technical staff of the hospital". The appellant who was no doubt a clinical staff was investigated for a missing stainless bowl but later terminated without following the process stipulated in the statute. The Supreme Court held that where the contract of appointment is determinable by the agreement of the parties simpliciter, there is no question of the contract having statutory flavour. The fact that the respondent is a creation of statue does not elevate all its employees to that status. The relevant conditions stated in the appellant's letter of appointment and the staff Regulations and Conditions of Service are what must be construed and nothing else. The fact that the respondent employer is a statutory body does not mean that the condition of service of its employees must be of a special character thereby ruling out the relationship of mere master and servant 33. The court conceded that if the determination of appellant's appointment had fallen under section 9 of the University Teaching Hospitals (Reconstitution of Boards etc.) Act, 1985, the situation would have been different. It however remains to be seen why the appellant's case was not brought within that statutory provision being a nursing officer and obviously a clinical staff in the respondent's hospital. Seeing the seemingly irreconcilable differences in these decisions, learned counsel in Idoniboye v. Nigerian National Petroleum Corporation 34 urged the Supreme Court to reconsider its earlier decision in Imoloame 35 and Fakuade 36.

It should be noted that the Court of Appeal in Iloabachie v. Philips 37 in following Fakuade held that the mere fact that a person is a pensionable federal public servant does not mean his contract of employment is protected by statute. The same court in Adeniran v. NEPA 38 decided that NEPA being a statutory body was bound by the rules of natural justice in the process of removal of its officers from office. However, in Isievwore $v$. NEPA 39 a confirmed staff of NEPA was removed from office in similar circumstances without hearing as set out in the employer's handbook. It was held that he was an ordinary employee with no statutory flavour.

Finally in Iduniboye v. NNPC 40, the Supreme Court clarified the seemingly conflicting position of public servants and decided as follows:

1. What the cases of Imoloame, Fakuade, and Iserhienerhien is that where an employment is governed by rules and regulations backed by statue such as the Civil Service Rules, as to how the employment is made and determined, a person who claims to be a public servant and seeks protection of those rules and regulations must show that he was employed subject to those rules and regulations otherwise he cannot rely on them as protecting his employment.

2. An employment with statutory flavour, through basically creating a service relationship, goes beyond the notion of ordinary master and servant whose contractual 
obligation can summarily be determined effectively albeit in breach of contract for the only remedy is damages.

3. The fact that an organisation or authority which is an employer is a statutory body does not mean that the conditions of service of its employees must be of a special character which make the employment one with a statutory flavour and give protection to the employees.

4. Where an appointment is determinable by the agreement of the parties simpliciter in accordance with the terms of the contract of service, under no guise can statutory flavour be attached to it but it must be regarded as mere master an servant relationship.

5. Conditions of service which will give statutory flavour to a contract of service cannot be a matter of inference. They must be conditions which are expressly set out by statute such as section 17 of the University of Lagos Act, 1967 or statutory regulations made under a subsidiary regulation such as the Civil Service Rules. Thus, a regulation with statutory flavour must be enacted by the Parliament or any law-making body as a schedule to an Act or Law or as a subsidiary legislation. Conditions drawn up by the Board of Directors of a statutory body have no statutory flavour.

In Olaniyan's case, apart from the memorandum of Appointment which was the Agreement between the parties containing the terms and conditions of service, there was the University of Lagos Act, 1967. Under section 17(i) of that Act, provisions for disciplinary measure against certain categories of officers and staff are made. The Act sets out the procedure that must be followed to remove such employees from service. When the mandatory procedure is not complied with, any disciplinary action taken against them will be declared null and void. It is those statutory provisions that are regarded as giving them some measure of security and protection. In that sense, the employment has a statutory flavour. It cannot be easily determined as that of a mere servant not having such protection. It is not a similar grounds that the removal of officers were nullified in ShittaBey; Eperokem, Laoye, Nnoli etc.

The reasoning in these cases had been succinctly discussed by the Supreme Court and distinguished Inmoloeme and Fakuade.

It is now established that the court cannot be called to draw an inference that an employment is with statutory flavour. To establish an employment with statutory flavour the rules and regulations claimed by the employee to be part of his terms and conditions of employment must be statutory rules. The Rules capable of giving statutory flavour and protecting the employee must:

a) have statutory reinforcement or at any rate be regarded as mandatory;

b) be directly applicable to the employee or person of his cadre;

c) be seen to be intended for the protection of that employment;

d) have been breached in the course of determining the employment; before they can be relied upon to challenge the validity of that determination. In other words, before an employment can be said to have statutory flavour, the statute must expressly make it so. Otherwise, the employment will have to be treated on the basis of the common law principle of master and servant.

In conclusion, the employment of public officers and their removal from office is an area where private and public law rights have found an uneasy convergence. A lot of confusion has been generated because of the complexity introduced by mixing up of the salient 
principles of law which has made the position of some public servants an intractable situation. The Supreme Court however rightly outlined the proper application of private and public law rights to public servants in proper sequence.

\section{Author Biography}

Dr. Kayode O. Fayokun (PhD) is a lecturer in Law at Obafemi Awolowo University, IleIfe, Nigeria. He holds a PhD in Law and a Certificate of the Conflict Resolution Workshop of the California State University, Sacramento, United States of America.

\footnotetext{
${ }^{a}$ Chianu, Emeka (2004) Employment Law, Bemico Publishers Nig. Ltd. P. 94

b (1985) 1 All NLR (pt.1) p. 256

c [1998] II NWLR (pt. 574) 524

${ }^{d}$ [2001] 21 WRN 161

e [2002] 15 NWLR (pt. 790) 376

f [2002] 15NWLR (pt. 790) 376

g (1981) NSCC 19; (1981) I SC 40

h. Taiwo v. Kingsway stores Ltd. 19 NLR 122

i Taiwo v. Kingsway Stores Ltd. Supra

${ }^{j}$ Ajayi v. Texaco Nig. Ltd. and 2 ors. [1987] 3 NWLR 577

${ }^{k}$ Ajayi v. Texaco Nig. Ltd Supra
} 